\title{
ADEUS REFORMISMO - PAPA FRANCISCO E A DOUTRINA SOCIAL DA IGREJA
}

Farewell to Reformism - Pope Francis and the Social Doctrine of the Church

Fábio Régio Bento *

RESUMO: O objetivo do presente artigo é analisar a mudança de orientação que está ocorrendo na Doutrina Social da Igreja no pontificado de Papa Francisco, com uma virada na orientação tradicional reformista desse conjunto de documentos, sobretudo encíclicas sociais papais que, desde a Rerum Novarum (1891), do papa Leão XIII, apresentavam uma posição reformadora como orientação geral de fundo da Igreja Católica em sua relação com o sistema capitalista.

PALAVRAS-CHAVE: Doutrina Social da Igreja. Papa Francisco. Movimentos Populares.

\begin{abstract}
The aim of this article is to analyze the change of orientation that is taking place in the Social Doctrine of the Church in the pontificate of Pope Francis, with a reversal in the traditional reformist orientation of this set of documents. This is, especially, in the papal social encyclicals that since the Rerum Novarum (1891) of Pope Leo XIII, have presented a reforming position as a general guiding principle of the Catholic Church in its relationship with the capitalist system.
\end{abstract}

KEYWORDS: Social Doctrine of the Church. Pope Francis. Popular Movements.

\footnotetext{
* Universidade Federal do Pampa, Bagé, RS, Brasil.
} 


\section{Introdução}

$\mathrm{Q}$ uando o argentino Jorge Bergoglio foi eleito papa, em 2013, tornando-se Papa Francisco, ele adotou um modo diferente de interpretar e avaliar o sistema capitalista. Francisco, ao contrário dos papas anteriores que escreveram sobre o sistema capitalista, em vez de aderir ao tradicional reformismo da Doutrina Social da Igreja, adotou uma posição profundamente crítica, antissistêmica em relação ao capitalismo. E tal posição antissistêmica em relação ao capitalismo é acompanhada por sua opção preferencial pelos movimentos populares internacionais como sujeitos protagonistas da transformação sistêmica internacional-local. Para Francisco, a transformação sistêmica é papel, sobretudo, da base da pirâmide da desigualdade de poder. Dessa forma, ao priorizar os movimentos populares internacionais como interlocutores no diálogo sobre as questões sociais internacionais-locais, manifesta sua posição pela centralidade da base, não pelo vértice dirigista dessa pirâmide, nos processos de transformação sistêmica, como veremos ao longo desse breve artigo.

\section{Adeus reformismo}

Desde o Papa Leão XIII, com a sua encíclica Rerum Novarum (1891), sobre as coisas novas que, aliás, nem eram tão novas assim mesmo em 1891, a posição dos papas em relação ao capitalismo foi uma posição pelas reformas voltadas para amenizar os males desse sistema internacional-local. Francisco irá além do reformismo. Adotará uma posição antissistêmica em relação ao sistema capitalista, o que não exclui as reformas sociais (reforma como meio), mas a legitimação parcial do sistema contida no reformismo (reforma como fim).

A crítica radical do sistema (mudança de sistema) adotada por Francisco não coincide com a estratégia reformista (mudanças no sistema) adotada anteriormente.

De fato, da encíclica Rerum Novarum (1891) até a Centesimus Annus (1991), de João Paulo II, publicada para celebrar o primeiro centenário da Doutrina Social da Igreja, emerge a "aposta na corrigibilidade do capitalismo", a convicção de que "o capitalismo, com as devidas correções, pode produzir benefícios” (ORDUÑA, 1993, p. 601, 602).

Nesses cem anos, as condenações papais "visaram explicitamente apenas aos abusos do sistema capitalista e nunca ao próprio capitalismo como sistema" (BOFF, C., 1978, p. 88). Pretendia-se transformar o capitalismus effrenus - traduzido impropriamente como "selvagem", como se a selva fosse sem freios - num capitalismo com freios reformadores. 
Por ocasião do lançamento da Centesimus Annus, em 1991, que ocorreu no contexto ufanista de celebrações da "vitória do capitalismo sobre o socialismo", o sindicalista italiano Giorgio Benvenuto (1991, p.41) resumiu assim a posição dessa encíclica de João Paulo II em relação ao capitalismo:

É justo sustentar que a Centesimus Annus não é contra a economia capitalista [...] Ela não demoniza a economia de mercado, mas propõe, em nível mundial, uma humanização e uma correção de rumo capaz de impedir o advento de um capitalismo selvagem.

Como resumiu Exequiel Rivas (1994, p.40), João Paulo II propôs o "capitalismo com rosto humano como opção válida para um cristão", batizando tal capitalismo literalmente de "novo capitalismo" (JOÃO PAULO II, 1991, n. 40a), para a alegria dos que defendiam, como o estadunidense Michael Novak (1987), uma espécie de relação de afinidade entre catolicismo e capitalismo. Em suma, como constatou Michael Löwy (2016), "existe uma longa tradição de crítica do capitalismo liberal, ou dos 'excessos' do capital na Igreja Católica. Mas nenhum Papa foi tão longe nesta condenação como Francisco".

\section{Um papa antissistêmico e pela centralidade da base}

A posição de Francisco, como veremos, não representa solução de continuidade com esse reformismo que via joio, mas, também, trigo no capitalismo. E onde se manifesta sua crítica mordaz do capitalismo? No mesmo lugar político onde se manifesta também sua opção preferencial pelos sujeitos coletivos de base como protagonistas da transformação sistêmica internacional-local: nos seus encontros com os movimentos populares internacionais.

\section{$2.1 I^{o}$ Encontro com os movimentos populares}

O primeiro encontro de Francisco com os movimentos populares internacionais ocorreu em outubro de 2014. A convite do Papa, líderes de Movimentos Populares dos cinco continentes se reuniram em Roma durante três dias de trabalho sobre três temas fundamentais: terra, teto e trabalho. "O Papa Francisco não se esqueceu de nós", declarou um dos organizadores do evento, Juan Grabois, responsável pela Confederação dos Trabalhadores da Economia Popular." "Jorge Bergoglio nos acompanhou por anos no processo de organização dos recicladores, camponeses, vendedores ambulantes, artesãos e herdeiros da crise provocada pelo capitalismo neoliberal", acrescentou Grabois. ${ }^{2}$

\footnotetext{
${ }^{1}$ Cf. I Encontro com movimentos populares. Disponível em: http://www.news.va/pt/news/a-cultura-do-encontro-a-servico-dos-pobres-movimen

${ }^{2}$ I Encontro com movimentos populares. Disponível em: http://www.news.va/pt/news/a-cultura-do-encontro-a-servico-dos-pobres-movimen. Acesso em: 14/12/2017.
} 
A conclusão da primeira jornada de trabalhos foi feita pelo líder do Movimento dos Sem-Terra (MST), João Pedro Stédile. Entre os movimentos populares brasileiros, além do MST estavam também representantes do Movimento de Mulheres Camponesas, Articulação dos Povos Indígenas do Brasil e a Coordenação Nacional de Entidades Negras. ${ }^{3}$

No dia 28 de outubro de 2014, Papa Francisco discursou para os representantes dos movimentos populares internacionais. Portanto, tratou sobre questões de exclusão sistêmica num evento específico não com intelectuais de academia, prelados da cúria romana, bispos de dioceses do mundo, empresários dos cinco continentes, mas com movimentos populares de excluídos do sistema internacional.

Em seu discurso sustentou que "os pobres lutam contra a injustiça", "querem ser protagonistas", "organizam-se", não ficam esperando por "planos assistenciais" que os querem "anestesiar ou domesticar" (FRANCISCO, 2014, p. 1). Destacou que é preciso "lutar contra as causas estruturais da pobreza", "fazer face aos efeitos destruidores do império do dinheiro" (Ibidem, p. 2), e criticou o que chamou de "estratégias de contenção", porque elas "só tranquilizam e transformam os pobres em seres domesticados e inofensivos" (Ibidem, p. 2). E ainda: "Sente-se o vento de promessa que reacende a esperança num mundo melhor. Que esse vento se transforme em furacão de esperança. Eis o meu desejo" (Ibidem, p. 2). Furacão para varrer o que ele chamou de "cultura do descarte", produzida por um sistema econômico centrado no "deus dinheiro", e não no ser humano (Ibidem, p. 4). Para Francisco, tal "sistema econômico centrado no deus dinheiro tem também necessidade de saquear a natureza" (Ibidem, p. 6), tema ao qual dedicará uma sua Carta Encíclica, no ano seguinte, 2015, intitulada Laudato Si': sobre o cuidado da casa comum.

Sobre o que chamou de "império do dinheiro", já finalizando seu discurso, destacou: "Alguns de vós disseram: este sistema já não funciona. Devemos mudá-lo", construir "estruturas sociais alternativas" (FRANCISCO, 2014, p. 6). Essa a posição dos movimentos populares, que Francisco assume como própria nessa sua dupla posição, ao mesmo tempo antissistêmica e pela centralidade da base na luta contra essa pirâmide de dominação.

De fato, para Francisco, na realização dessa tarefa mundial-local, o protagonismo é dos excluídos organizados em seus movimentos populares de ação e pertencimento. Alegra-se com a dinâmica criativa desses movimentos de excluídos "que crescem de baixo, do subsolo do planeta" (Ibidem, p. 7), e que não devem ser contidos em "estruturas rígidas" (Ibidem, p. 7). Para ele,

Os movimentos populares expressam a necessidade urgente de revitalizar as nossas democracias, tantas vezes desviadas por inúmeros fatores. É

${ }^{3}$ Ibidem. 
impossível imaginar um futuro para a sociedade sem a participação como protagonistas das grandes maiorias e este protagonismo transcende os procedimentos lógicos da democracia formal. A perspectiva de um mundo de paz e de justiça duradouras pede que superemos o assistencialismo paternalista, exige que criemos novas formas de participação que incluam os movimentos populares e animem as estruturas de governo locais, nacionais e internacionais com aquela torrente de energia moral que nasce da integração dos excluídos na construção do destino comum (FRANCISCO, 2014, p. 7).

Movimentos populares como torrente de energia moral, criativa. Protagonistas da mudança de sistema na construção coletiva, a partir dos excluídos, da sociedade da inclusão. O que é diferente de ser objeto da tutela assistencial do dirigismo de vértice.

\subsection{Movimentos populares e Francisco na Bolívia}

O segundo encontro mundial dos movimentos populares com Francisco ocorreu na Bolívia, em julho de 2015. O evento contou com a participação de 900 organizações sociais de diversos continentes, com forte participação de delegações da América Latina, por razões de proximidade geográfica. O encontro ocorreu sem solução de continuidade com o anterior, consolidando essa iniciativa inédita de um papa de tratar sobre questões sociais diretamente com os movimentos de base organizados pelos excluídos do sistema econômico mundial. Com os pobres e seus movimentos, em vez de para os pobres.

Em seu discurso, após relatar que recebeu várias cartas narrando múltiplas formas de exclusão, Papa Francisco (2015c, p. 2) destacou:

Mas há um elo invisível que une cada uma das exclusões. Não se encontram isoladas, estão unidas por um fio invisível. Conseguimos nós reconhecê-lo? É que não se trata de questões isoladas. Pergunto-me se somos capazes de reconhecer que estas realidades destrutivas correspondem a um sistema que se tornou global. Reconhecemos nós que este sistema impôs a lógica do lucro a todo custo, sem pensar na exclusão social nem na destruição da natureza?

A dramaticidade da exclusão e destruição do "solo, água, ar e todos os seres da criação" (Ibidem, p. 2) indica que o sistema precisa ser urgentemente transformado caso se queira evitar o apocalipse ambiental:

Digamo-lo sem medo: Queremos uma mudança, uma mudança real, uma mudança de estruturas. Este sistema é insuportável: não o suportam os camponeses, não o suportam os trabalhadores, não o suportam as comunidades, não o suportam os povos... E nem sequer o suporta a terra, a irmã Mãe Terra, como dizia São Francisco (Ibidem, p. 2).

Sua crítica radical do capitalismo como sistema que precisa ser freado também pelo risco de colapso do planeta, pela destruição da terra, do ar 
e da água, assemelha-se à consideração feita por um leigo, ecossocialista, Michael Löwy. Para ele o capitalismo, se não for contido, talvez seja não uma etapa, mas a última etapa da história da humanidade pela sua crescente capacidade de destruição ambiental comandada pelo imperativo da produção a qualquer custo. Para Löwy (apud QUERIDO, p. 96), de fato,

Se acreditamos com Rosa Luxemburgo que o socialismo não é inelutável e que a crise do capitalismo pode conduzir à barbárie, se tomamos a sério as advertências de Walter Benjamin de que a finalidade do progresso pode ser a catástrofe, como é possível pretender que o progresso capitalista seja de alguma forma bem-vindo?

Francisco (2015c, p. 7) rejeita esse sistema que sacrifica a "Mãe Terra" no "altar da produtividade". Sua posição, portanto, não pode ser classificada dentro daquele padrão reformista anterior que identifica pontos positivos e negativos no capitalismo, com a proposta de manter o que é bom e mudar somente os pontos negativos. Ele não ameniza suas críticas com expressões arrefecedoras da linguagem liberal-burguesa, adotada também em âmbito católico, como economia de mercado, ou economia social de mercado.

Nem a palavra "progresso", tão amada pelo positivismo burguês e por alguns incautos socialismos, escapa de sua crítica. De fato, em sua Encíclica Laudato si' - Sobre o cuidado da casa comum, Francisco (2015b, n. 194) destacou que é preciso "redefinir o progresso": "um desenvolvimento tecnológico e econômico que não deixa um mundo melhor e uma qualidade de vida integralmente superior não pode ser considerado progresso".

A ideologia burguesa do progresso, portanto, não conta com o apoio de Francisco. Progresso para quem? Qual o custo do progresso? Na Bolívia, Francisco (2015c, p. 3) destacou também que

Quando o capital se torna um ídolo e dirige as opções dos seres humanos, quando a avidez de dinheiro domina todo o sistema socioeconômico, arruína a sociedade, condena o ser humano, transforma-o em escravo, destrói a fraternidade inter-humana, faz lutar povo contra povo e, até, como vemos, põe em risco esta nossa casa comum, a irmã e mãe terra.

Francisco agrupou vários problemas sociais ao redor de uma causa central-estrutural, o sistema focado na acumulação permanente de capital que, para ele, está constitutivamente em contradição com a "fraternidade inter-humana" e o equilíbrio ambiental.

Alguns meses antes do encontro na Bolívia, de fato, na audiência geral de quarta-feira, 21 de janeiro de 2015, ele já destacara que

a causa principal da pobreza é um sistema econômico que deslocou a pessoa do centro e ali colocou o deus dinheiro; um sistema econômico que exclui, exclui sempre: exclui as crianças, os idosos, os jovens, sem trabalho... e que cria a cultura do descarte em que vivemos (FRANCISCO, 2015a). 
Francisco abre, portanto, um capítulo novo na história da Doutrina Social da Igreja Católica. Um capítulo diferente, antissistêmico e pela centralidade do protagonismo dos excluídos nos processos históricos de inclusão.

Até sobre o tradicional princípio da subsidiariedade (MAGAGNOTTI, 1991), interpretado pelos católicos burgueses como liberdade econômica dos empresários frente aos "abusos" do Estado, Francisco sugere uma interpretação diferente, como subsidiariedade popular, protagonismo da base, dos excluídos organizados em seus movimentos na construção da sociedade da inclusão. Para Francisco (2015c, p. 7), de fato, no "processo de mudança" os movimentos populares são os "poetas sociais". É deles o protagonismo: "Os povos do mundo querem ser artífices do seu próprio destino", destacou (Ibidem, p. 8), "não querem tutelas nem interferências, onde o mais forte subordina o mais fraco" (Ibidem, p. 8).

Do ponto de vista das mudanças sociais, Francisco concentra sua atenção na questão das mudanças de ordem estrutural, pela superação de um sistema gerador da negação prática, cotidiana, da fraternidade inter-humana. Dessa forma, criticou a posição dos que fogem do terreno da busca de mudanças estruturais sustentando "que não haja nada que se possa fazer para além de cuidar de nós mesmos e do pequeno círculo da família e dos amigos" (2015c, p. 3). O horizonte político de Francisco - sem excluir, ao contrário, valorizando o terreno do microssocial e da "conversão sincera das atitudes e do coração" (Ibidem, p. 4) - é o horizonte da mudança de sistema. E o sujeito-chave nesse processo de luta antissistêmica é sujeito de base, os movimentos populares internacionais-locais:

Que posso fazer eu, recolhedor de papelão, catador de lixo, limpador, reciclador, frente a tantos problemas, se mal ganho para comer? Que posso fazer eu, artesão, vendedor ambulante, carregador, trabalhador irregular, se não tenho sequer direitos laborais? Que posso fazer eu, camponesa, indígena, pescador que dificilmente consigo resistir à propagação das grandes corporações? Que posso fazer eu, a partir da minha comunidade, do meu barraco, do meu povoado, da minha favela, quando sou diariamente discriminado e marginalizado? Que pode fazer aquele estudante, aquele jovem, aquele militante, aquele missionário que atravessa as favelas e os paradeiros com o coração cheio de sonhos, mas quase sem nenhuma solução para os seus problemas? Podem fazer muito. Vós, os mais humildes, os explorados, os pobres e excluídos, podeis e fazeis muito. Atrevo-me a dizer que o futuro da humanidade está, em grande medida, nas vossas mãos, na vossa capacidade de vos organizar e promover alternativas criativas na busca diária dos três " $\mathrm{T}$ " - entendido? - (trabalho, teto, terra), e também na vossa participação como protagonistas nos grandes processos de mudança, mudanças nacionais, mudanças regionais e mudanças mundiais. Não se acanhem! (Ibidem, p. 3-4).

Um papa, portanto, com uma posição antissistêmica e a favor da centralidade do protagonismo dos excluídos, organizados em seus movimentos 
mundiais-locais, no trabalho popular de substituição do atual sistema, focado na acumulação de capital, por um sistema diferente, fundado na inclusão. Para isso, porém, Francisco (2015c, p. 6) não apresenta uma sua fórmula, nem indica uma terceira, quarta, ou quinta via alternativa em relação ao capitalismo: "Nem o Papa nem a Igreja têm o monopólio da interpretação da realidade social e da proposta de soluções", "não existe uma receita". O que ele faz é tornar seu o método de construção dessa nova sociedade que ele identificou como sendo o método dos movimentos populares internacionais:

Aqui, na Bolívia, ouvi uma frase de que gosto muito: "processo de mudança". A mudança concebida não como algo que um dia chegará porque se impôs esta ou aquela opção política ou porque se estabeleceu esta ou aquela estrutura social (...). A opção é a de gerar processos e não a de ocupar espaços (Ibidem, p. 4).

Processo de mudança protagonizado permanentemente pelas organizações de base, pelos movimentos populares, identificando rumos e trabalhando para realizar mudanças estruturais locais, regionais, mundiais.

Depois do encontro na Bolívia, em novembro de 2016 Francisco voltou a se encontrar com os movimentos populares, novamente em Roma, como no primeiro encontro. Nesse terceiro encontro confirmou as teses dos encontros anteriores, não amenizou suas críticas. Em vez de adotar um tom mais moderado, como esperavam os católicos conservadores, classificou como "terrorista" o sistema econômico internacional do "controle global do dinheiro", gerador de exclusão, de imigração e morte: "Este sistema é terrorista" (FRANCISCO, 2016, p. 3). E, citando parte de um discurso pronunciado alguns meses antes, completou: "o terrorismo começa quando 'se expulsa a maravilha da criação, o homem e a mulher, colocando no seu lugar o dinheiro'" (Ibidem, p. 3). Portanto, nada de amenidades com o sistema da acumulação permanente e incessante de capital.

\section{Um papa do sul político do mundo}

Papa Francisco está sendo uma grata surpresa para os movimentos populares e para os intelectuais-militantes, leigos e católicos, que pesquisam e agem orientados pelo horizonte político e epistemológico da libertação dos oprimidos, que é o horizonte também de Frei Betto, dominicano, escritor brasileiro que atravessou a turbulência política neoliberal sem abandonar sua posição antissistêmica em relação ao capitalismo e pelo protagonismo dos movimentos populares nos processos de transformação social, dois pontos políticos em comum entre o frei brasileiro e o papa argentino.

E atravessou com a mesma firmeza ideológica também a turbulência conservadora do papado de João Paulo II, quando católicos de esquerda 
foram sistematicamente combatidos desde o Vaticano, com o fechamento de institutos de teologia, troca de bispos, censura a teólogas e teólogos. Assim, a chegada de Francisco e suas primeiras ações foram acolhidas como boa-nova também por ele.

Em setembro de 2016, na Itália, onde encontrava-se para o Festival Internacional de Literatura de Mântua, em uma entrevista, Frei Betto (2016) afirmou: "Em mais de 70 anos eu não tinha visto um milagre na Igreja, desde a eleição do Papa João XXIII. Eu pensava que algo assim nunca mais voltaria a acontecer. E outro milagre aconteceu: a eleição de Bergoglio, o Papa Francisco".

Para o brasileiro, "Francisco é, efetivamente, o primeiro Papa que fala das causas das injustiças no mundo" (BETTO, 2016). Papas anteriores criticaram os efeitos do capitalismo, mas

Francisco vai além, aponta as causas. Nenhum Papa havia feito isso antes. Em sua encíclica Laudato Si' ele aponta que a desigualdade vem de um sistema que tem o capital como prioridade e não os direitos humanos. Disse que o problema ecológico não pode ser visto sem levar em conta o aspecto social, porque o desequilíbrio ambiental afeta, sobretudo, os mais pobres (Ibidem).

Betto, porém, mesmo destacando que "é uma alegria que Deus tenha dado à Igreja um homem como Francisco", acrescentou: "Não acredito muito em que vai haver um milagre de conversão da cúria romana. Há muitos interesses em jogo aí, mas acredito em que a Igreja pode se renovar" (Ibidem).

Para Francisco "o clericalismo é uma peste na Igreja" ${ }^{4}$, mas é impossível prever se um papa cristão poderá ser exitoso na transformação dessa estrutura milenar pesada, monárquico-clerical que em alguns aspectos representa mais a degeneração estrutural do que a realização do cristianismo de Cristo. Entretanto, ele tenta transformar a Igreja e o mundo a partir e junto com os excluídos. E nisso ele manifesta que não é somente um papa geograficamente do sul do mundo, mas, também, com um pensamento de sul político do mundo. Nesse sentido, no item conclusivo desse artigo, apresentaremos algumas citações que não são de Francisco, mas que, a nosso aviso, estão em sintonia com seu pensamento antissistêmico e pela centralidade dos excluídos. Entraremos nesse item conclusivo orientados pela seguinte pergunta: qual o sentido teológico da opção pela centralidade da base nos "processos de mudança" numa perspectiva teológica politicamente austral?

${ }^{4}$ FRANCISCO, Papa. Entrevista. Disponível em: http://www.ihu.unisinos.br/78-noticias/567623-o-clericalismo-e-uma-peste-na-igreja-entrevista-com-o-papa-francisco-no-voo-de-volta-de-fatima. Acesso em: 27/12/2017. 


\section{Sentido político-teológico da centralidade da base}

O fundamento político-teológico da centralidade da base é crístico: o fundador do cristianismo contestou o sistema confessional de dominação política que vigorava em seu tempo, posicionando-se ao lado dos excluídos desse sistema, pela sua inclusão, e foi por ter contestado tal sistema confessional de dominação e exclusão a partir do lugar histórico-político da exclusão que ele foi condenado a morte e executado. Dessa forma, seguir o ensinamento de Cristo significa, também, ocupar no tempo-espaço o lugar ocupado pelos excluídos e interpretar a sociedade onde se vive a partir desse lugar político-teológico específico.

Para o dominicano Frei Betto (1990, p. 923),

Jesus se colocou no lugar dos pobres, mas sem ceder ao pieguismo de uma solidariedade sacralizadora da pobreza; ao contrário, procurou trazê-los da periferia ao centro, da marginalização à conquista do direito, da enfermidade à cura, da fome ao pão, da tristeza à alegria, da culpa ao perdão, do pecado à graça, da morte à vida.

O lugar do pobre é o lugar de Cristo, e o lugar de Cristo é o lugar dos cristãos, portanto, também do Papa Francisco. A base dessa pirâmide de dominação torna-se assim o lugar da interpretação da dominação e das ações políticas voltadas para a contestação-superação das formas estruturais de dominação-subordinação de seres humanos por seres humanos.

Em A Trindade, a sociedade e a libertação, Leonardo Boff $(1986$, p. 14; 177; 281) explicou que Jesus contestou o sistema de subordinação porque contrário ao estilo constitutivo de vida da Trindade, caracterizado pela unidade na distinção, sem relações de subalternidade e subordinação entre as pessoas divinas. A Trindade, assim, referência vital e paradigmática de Cristo nas suas relações históricas na Palestina, serve, também, de referência paradigmática para os cristãos na contestação das relações históricas de subalternidade e subordinação. Dessa forma, o lugar do pobre é o lugar de Cristo porque o lugar de Cristo é a Trindade, "a melhor comunidade", na expressão usada no movimento da Teologia da Libertação. Comunidade divina que contesta as relações históricas não-trinitárias de dominação e subalternidade que se manifestam nas modalidades leigas e confessionais de dirigismo de vanguarda: dominação burguesa, "socialismo" de vértice, clericalismo.

O lugar do pobre, porém, como destacou Betto (1990, p. 923), não é lugar de acomodação, mas de contestação: "A pobreza tem causas estruturais, o que significa, a rigor, que não há pobres (pois ninguém escolhe sê-lo, e os que o são gostariam de viver em melhores condições), há pessoas empobrecidas", e é nesse sentido que "a teologia da libertação chama o pobre de oprimido". Pobre como empobrecido por um sistema que realiza 
metodicamente a produção de pobreza e riqueza. Sistema que no tempo de Cristo era político-confessional e foi por ele contestado.

Como explicou Alberto Maggi (2003, p. 33), doutor em exegese dos quatro evangelhos, "um dos maiores e mais trágicos equívocos" foi interpretar a mensagem de Jesus como se ele "tivesse dito que os pobres são bem-aventurados porque vão para o paraíso". Para Maggi (Ibidem, p. 33) não é assim: "nos evangelhos há referências seja aos pobres que à pobreza, contudo nunca para beatificar esta condição, nunca para sublimá-la e exaltá-la, mas sempre para eliminá-la. Jesus veio para eliminar as causas da pobreza".

Segundo o teólogo católico italiano, "todo o ensinamento de Jesus é dirigido à eliminação das causas da pobreza" (Ibidem, p. 35). Nesse sentido, continua Maggi (Ibidem, p.35), "a ação de Jesus não é espiritual, não diz respeito somente a um hipotético reino dos céus, um paraíso, mas diz respeito à sociedade, que Jesus veio para mudar profundamente". Entretanto, como essa mensagem é difícil de aceitar, terminaram ao longo dos anos por "espiritualizar" Jesus (Ibidem, p. 35).

Jesus, porém, ocupou o lugar do pobre, e pela sua libertação. Não ocupou o vértice, mas a base da pirâmide de poder de seu tempo, posicionando-se pelo fim dessa pirâmide político-confessional de poder. Segundo Maggi (Ibidem, p. 76), de fato, no tempo de Jesus

a sociedade era concebida de forma piramidal. Acima da pirâmide pairava Deus. No vértice estava o sumo sacerdote ou o rei que, às vezes, exerciam a mesma função: o sumo sacerdote era também rei, o rei era também sumo sacerdote. Em seguida, os sacerdotes, os príncipes, etc. Na última camada dessa pirâmide estavam os servos. Na parte debaixo dela, sem direitos civis, estavam os escravos.

Dessa forma, as organizações piramidais, político-dirigistas, estão em contradição com o ensinamento dos evangelhos:

Em todas as religiões se apresenta um Deus que cria os seres humanos para ser servido por eles. Jesus diz: “Isso é falso. É Deus que está a serviço dos seres humanos". Então surge o terror da parte das autoridades religiosas. Porque um Deus que domina é um Deus do poder que justifica o poder e domínio dessas autoridades religiosas. Mas se as pessoas começam a acreditar que Deus está a serviço dos seres humanos, a única maneira de representá-lo é aquela de se colocar a serviço desses seres humanos e isso aterroriza quem detém o poder. Eis porque assassinarão Jesus (MAGGI, 2003, p.75).

Qual foi a resposta-posição de Jesus em relação a tal sistema organizacional de caráter político-confessional? Nos evangelhos, Jesus mostrou que "Deus não está no alto, no vértice do poder de quem comanda. Deus está embaixo, em quem serve" (Ibidem, p. 76). E ainda: "Deus age com os seres humanos a partir de baixo para elevá-los ao seu mesmo nível. O Senhor realiza o trabalho de servo para que os servos sejam senhores" (Ibidem, p. 
77). E senhor não significa poder mandar em alguém, mas não ser mandato por ninguém, "não ter ninguém acima de mim, ser plenamente livre na prática de um amor semelhante ao seu" (Ibidem, p. 39).

O lugar de Cristo, portanto, é o lugar do excluído do sistema, a base da pirâmide, o lugar do pobre como lugar epistemológico e político de libertação. Lugar para a transformação estrutural que é adiada, porém, para o "céu" pelos reacionários crentes que interpretam o cristianismo de forma conservadora, usando o "céu" como instrumento ideológico para a legitimação e manutenção dos sistemas de exclusão que os beneficiam na terra.

Para Leonardo Boff (1986b, p. 9), se a realidade for vista a partir do lugar do pobre, "então fica claro como a realidade deve ser transformada, pois ela é demasiadamente iníqua para a maioria dos homens; ela os empobrece e marginaliza". Reflexões que, a nosso aviso, não estão em contradição, mas em relação de afinidade com as de Francisco sobre a necessidade dos processos de mudança dentro e fora da Igreja, protagonizado pelos excluídos em sua luta evangélica contra as formas leigas e confessionais de dominação.

\section{Conclusão}

Nesse artigo afirmamos que Papa Francisco abriu novo capítulo na história da Doutrina Social da Igreja ao trocar o reformismo tradicional que o precedeu, que condenava somente os "abusos" do sistema, pela crítica do sistema em si, considerando-o como uma ameaça à humanidade pela produção permanente, sistemática de exclusão, descarte de seres humanos e destruição ambiental.

Entre os críticos de Francisco, há quem sustente que se trata de um "papa utópico", que alimenta "ilusões políticas" dado que o capitalismo é muito mais forte do que seus opositores e, portanto, seria um sistema indestrutível, mesmo se destruidor.

Segundo a lógica desses "católicos realistas", "não-utopistas" como, segundo eles, seria Francisco, o melhor seria continuar insistindo apenas com as reformas, buscando o "diálogo construtivo" com os dirigentes internacionais do capitalismo mundial, em vez de se unir aos sem-poder dos movimentos populares internacionais. Afinal, ainda segundo a crítica desses católicos "realistas", a terra não é o céu, mas um vale de lágrimas onde se pode, ao máximo, amenizar o sofrimento enquanto a irmã morte não chega.

A nosso aviso, a crítica de tais conservadores "moderados" manifesta, na melhor das hipóteses, quando não se trata de cumplicidade financeira mes- 
mo, a crença deles na eternidade histórica dos poderes fortes. Ora, assim como a hegemonia da monarquia, que parecia sólida, eterna, destinada ao infinito foi dissolvida no ar da história, nada nem ninguém garante eternidade histórica à hegemonia sistêmica da burguesia. Aliás, a parte da Igreja Católica que hoje considera o capitalismo como insuperável, assemelha àquela parte da Igreja que no passado considerou o sistema monárquico também insuperável.

Nesse sentido, a crítica de Francisco se sustenta na consideração realista da história como cemitério de hegemonias que antes de morrerem também foram tratadas como imortais, o que acontece hoje com o sistema capitalista sustentado pela hegemonia burguesa que se apresenta como se fosse eterno assim como no passado também o sistema monárquico também o fez. Em suma, assim como a hegemonia da monarquia findou, após séculos de vida apresentada como eterna e de origem "divina", ninguém assegura vida eterna no tempo e espaço para a hegemonia burguesa.

Capitalismo e hegemonia burguesa são mantidos a ferro, fogo e produção de sonhos de consumo em suas empresas de entretenimento, publicidade e manipulação de informações. Portanto, não é uma hegemonia natural, incontestável, insubstituível. Assim, a crítica de Francisco não se funda em ilusões, mas em possibilidades históricas de mutabilidade sistêmica pelo poder das organizações interessadas em tal mudança.

O prazo de validade de uma hegemonia depende de sua capacidade de eternizar-se camuflando, minimizando, justificando suas contradições, apresentando-se como necessária, inevitável, eterna. A monarquia se apresentou como poder eterno, de origem divina, parte constitutiva da ordem natural das coisas. Foi sustentada pela religião do medo. A burguesia e o capitalismo trocaram a religião do medo pela religião do prazer, do consumo, do lucro, com os "mistérios" do capital que, de tão sobrenatural que são não poderiam ser capturados pela cognição nem modificados pela ação política. Assim, apesar das suas tantas contradições, consegue convencer do contrário usando a máscara da beleza fictícia, eliminando do horizonte da maioria a visão real que poderia acelerar o seu declínio. Apesar da máscara do "progresso", porém, o capitalismo não é eterno.

O problema é que o capitalismo em vez de ser uma etapa da história da humanidade pode ser a última, por assemelhar a um trem em alta velocidade indo em direção não ao "progresso universal da humanidade", mas em direção ao abismo apocalíptico da destruição ambiental, animado pela lógica da produção pela produção que funciona como o frenesi das piranhas ao redor de um pedaço de carne, onde o pedaço de carne são os seres humanos e as demais formas de vida do planeta.

Se depender de Francisco, porém, e das suas amigas e amigos dos movimentos populares internacionais-locais, a ditadura do lucro continuará 
sendo combatida também para se evitar esse triste fim da humanidade via apocalipse ambiental.

\section{Referências}

BENTO, F. R. Cristianismo e democracia: da soberania dos "pastores" à soberania das "ovelhas". In: BENTO, F. R. (Org.). Cristianismo, humanismo e democracia. São Paulo: Paulus, 2005. p.19-47.

Igreja Católica e Revolução na América Central: quebra de paradigma na Nicarágua. Revista Conjuntura Austral, Porto Alegre, v. 7, n. 33-34, p. 16-32, dez. 2015; jan. 2016.

. Marxismo e religião: revolução e religião na América Central. São Paulo: Paco, 2016.

BENVENUTO, G. Unione tra valore del lavoro e quello della pace. In: GIOVANNI PAOLO II: Centesimus annus (Commenti). Roma: Logos, 1991. p. 41-46.

BETTO, Frei A teologia da libertação ruiu com o muro de Berlim? Revista Eclesiástica Brasileira, Petrópolis, v. 50, fasc. 200, p. 922-929, dez. 1990.

Entrevista em Mântua. Setembro 2016. Disponível em: http://www.ihu. unisinos.br/noticias/560650-francisco-e-o-primeiro-papa-que-fala-das-causas-da-injustica-no-mundo-entrevista-com-frei-betto. Acesso em: 07/12/2017.

BOFF, C. A justiça na história (II): capitalismo, socialismo, discernimento cristão. Revista de Cultura Vozes, Petrópolis, v. 72, p. 85-96, 1978.

BOFF, L. A Trindade, a sociedade e a libertação. Petrópolis: Vozes, 1986.

Do lugar do pobre. Petrópolis: Vozes, 1986b.

FRANCISCO, Papa. Discurso aos participantes no I Encontro mundial dos movimentos populares. Vaticano, 28 de outubro de 2014. Disponível em: <https://w2.vatican.va/ content/francesco/pt/speeches/2014/october/documents/papa-francesco_20141028_incontro-mondiale-movimenti-popolari.html>. Acesso em: 14 dez. 2017.

Audiência geral - quarta-feira, 21 de janeiro de 2015a. Disponível em: $<\mathrm{http}$ //w2.vatican.va/content/francesco/pt/audiences/2015/documents/papa-francesco_20150121_udienza-generale.html>. Acesso em: 15 dez. 2017.

Carta Encíclica Laudato Si': sobre o cuidado da casa comum. São Paulo: Loyola-Paulus, 2015b.

Discurso aos participantes no II Encontro mundial dos movimentos populares. Bolívia, julho de 2015c. Disponível em: <http://w2.vatican.va/content/francesco/ pt/speeches/2015/july/documents/papa-francesco_20150709_bolivia-movimenti-popolari.html>. Acesso em: 14 dez. 2017.

. Discurso aos participantes no III Encontro mundial dos movimentos populares. Vaticano, novembro de 2016. Disponível em: <http://w2.vatican.va/content/francesco/pt/ speeches/2016/november/documents/papa-francesco_20161105_movimenti-popolari. html>. Acesso em: 14 dez. 2017. 
Entrevista. Disponível em: <http://www.ihu.unisinos.br/78-noticias/567623-o-clericalismo-e-uma-peste-na-igreja-entrevista-com-o-papa-francisco-no-voo-de-volta-de-fatima>. Acesso em: 27 dez. 2017.

JOÃO PAULO II, Papa. Encíclica Centesimus annus (1991). Disponível em: <http:// w2.vatican.va/content/john-paul-ii/pt/encyclicals/documents/hf_jp-ii_enc_01051991_ centesimus-annus.html>. Acesso em: 14 dez. 2017.

LÖNNE, K.-E. Il cattolicesimo politico nel XIX e XX secolo. Bolonha: Il Mulino, 1991. LÖWY, M. Entrevista Correio da Cidadania. 30 jun. 2016. Disponível em: <https:// www.cartamaior.com.br/?\%2FEditoria\%2FInternacional\%2F-Nenhum-Papa-foi-tao-longe-na-condenacao-ao-capitalismo-como-Francisco-\%2F6\%2F36368\#.WkgqRmEcMKI.facebook>. Acesso em: 31 dez. 2017.

MAGAGNOTTI. P. Il principio di sussidiarietà nella dottrina sociale della chiesa. Bolonha: Studio Domenicano, 1991.

MAGGI, A. Il dio impotente. Senigallia, 2003. Disponível em: <https://www.studibiblici.it/conferenze/IL_DIO_IMPOTENTE.pdf>. Acesso em: 29 dez. 2017.

MARTINA, G. Storia della chiesa - l'età del liberalismo. Brescia: Morcelliana, 1995.

NOVAK, M. Lo spirito del capitalismo democratico e il cristianesimo. Roma: Studium, 1987.

ORDUÑA, R. R. Los sistemas económicos. In: CUADRÓN, A (Org.). Manual de doctrina social de la Iglesia. Madrid: Biblioteca de Autores Cristianos (BAC), 1993. p. 587-611.

QUERIDO, F. M. Michael Löwy: marxismo e crítica da modernidade. São Paulo: Boitempo, 2016.

RIVAS, E. Cem anos de doutrina social da igreja. In: IVERN, F.; BINGEMER, M. C. (Orgs.). Doutrina social da igreja e teologia da libertação. São Paulo: Loyola, 1994. p. 23-42.

SPINELLI, L. Lo Stato e la chiesa. Venti secoli di relazioni. Turim: Utet libreria, 1988.

Artigo submetido em 04.06.2018 e aprovado em 30.10.2018.

Fábio Régio Bento é Doutor em Ciências Sociais pela PUC San Tommaso (Roma, 1996). Pós-doutorado junto ao Núcleo de Estudos da Religião do PPGAS da UFRGS (2015). Professor associado na Universidade Federal do Pampa e professor colaborador da Universidade Estadual da Paraíba.Orcid.org/0000-0003-3796-1799. E-mail: fabiobento@unipampa.edu.br

Endereço: Rua Barão do Triunfo, 1048, Centro, Unipampa 97573-634 Santana do Livramento - RS 